\title{
Kajian Kebijakan PMW (Program Mahasiswa Wirausaha)
}

\author{
Hendarman \\ hendarmananwar@gmail.com
}

\begin{abstract}
ABSTRAK: Suatu program khusus bagi para mahasiswa, yaitu Program Mahasiswa Wirausaha (PMW) telah diluncurkan oleh Pemerintah melalui Kementerian Pendidikan Nasional pada tahun 2009. Kebijakan ini dimaksudkan untuk memfasilitasi para mahasiswa yang mempunyai minat dan bakat kewirausahaan untuk memulai berwirausaha dengan basis ilmu pengetahuan, teknologi dan seni yang sedang dipelajarinya. Keberadaan program ini didukung oleh kenyataan bahwa sebagian besar lulusan Perguruan Tinggi adalah lebih sebagai pencari kerja daripada pencipta lapangan pekerjaan. Program ini memberikan bantuan bagi mahasiswa yang layak dalam bentuk dana yang dapat digunakan secara perorangan dan kelompok. Tulisan ini merupakan kajian terhadap kebijakan PMW ditinjau dari persepsi mahasiswa terhadap pentingnya PMW dan keberhasilan usaha wirausaha mahasiswa. Responden kajian ini adalah para mahasiswa penerima bantuan PMW di beberapa perguruan tinggi negeri dan swasta. Temuan kajian adalah bahwa program ini memiliki dampak penting, yaitu membuka wawasan, kemampuan dan sikap mahasiswa dalam bewirausaha, serta membuka lapangan kerja bagi masyarakat. Evaluasi lebih lanjut terhadap besarnya hibah bagi masingmasing mahasiswa dan alokasi dana bagi perguruan tinggi perlu dikaji dengan memperhitungkan jumlah total mahasiswa dan keberhasilan mahasiswa PMW pada tahun sebelumnya di masing-masing perguruan tinggi.
\end{abstract}

Kata kunci: wirausaha, pendidikan tinggi, dan pengangguran

ABSTRACT: The government through the Ministry of National Education in 2009 has launched a special program for students at higher education institutions the so-called "Program Mahasiswa Wirausaha (PMW)". This program aims for facilitating students' interest and talent in entrepreneurship to be an entrepreneur based on their disciplines in science, technology, and arts. This program is also to respond to the fact that big percentages of higher education graduates become job-seeker instead of job-creator. This program provides students with grant either in person or in a group. This article analyses the implementation of PMW in the view of those students who took part in the program with two focuses, namely the importance of PMW and the achievement of students' grant-receiver. The respondents were from both public and private higher education institutions. The analysis revealed that the program have significant impact in broadening students' perspective, competences and attitude to be an entrepreneur, as well as opening new job-market for people. It is suggested to conduct another evaluation to analyse the appropriateness of grant given to students and financial allocation for each higher education institution by taking into consideration the total number of students and number of success students in PMW.

Key words: entrepreneur, higher education, and unemployment

\section{Pendahuluan}

Kualitas perguruan tinggi dalam melahirkan sarjana/ diploma terus dipertanyakan. Lulusannya dianggap tidak mampu menjawab kebutuhan pasar karena belum mampu berkreasi di dalam keterbatasan dan kurang berdaya juang di dalam tekanan. Mentalitas alumni perguruan tinggi lebih banyak yang pasif dan bertipe kuli yaitu hanya mengerjakan apa yang diperintahkan atasan, minim kreativitas, dan mandul inisiatif. Lapangan kerja rata-rata hanya menyerap $37 \%$ lulusan perguruan tinggi.
Dalam acara Rembuk Nasional Pendidikan 2008, Dirjen Pendidikan Tinggi Departemen Pendidikan Nasional mengangkat isu pengangguran yang terjadi tersebut. Diduga bahwa tingginya angka pengangguran disebabkan oleh berbagai faktor, di antaranya kompetensi keahlian tidak sesuai dengan kebutuhan pasar tenaga kerja, lulusan program studi sudah jenuh di masyarakat, atau tidak memiliki keahlian apapun untuk bersaing di dunia kerja. Terungkap bahwa lulusan yang kurang bisa bersaing di dunia kerja umumnya lulusan program studi ilmu-ilmu sosial. 
Sementara itu, lulusan fakultas teknik banyak dibutuhkan, tetapi kompentensi keahlian lulusannya masih kurang (Direktorat Jenderal Pendidikan Tinggi, 2009a).

Data Badan Pusat Statistik (BPS, 2008) menunjukkan bahwa tingkat pengangguran terbuka di Indonesia mencapai $7,87 \%$. Jumlah penduduk yang bekerja menurut pendidikan tertinggi yang ditamatkan untuk golongan SMK, diploma,dan universitas mengalami kenaikan. Untuk pekerja dengan pendidikan diploma hanya sebesar 2,79 juta orang atau sekitar 2,55 persen, dan pekerja dengan pendidikan sarjana hanya tercatat sebesar 4,66 juta orang atau mencapai 4,44 persen. Dari tahun ke tahun, jumlah pengangguran lulusan sarjana secara nyata lebih tinggi dibanding lulusan diploma. Data tersebut mengindikasikan bahwa setidak-tidaknya sekitar $20 \%$ dari jumlah lulusan perguruan tinggi setiap tahunnya belum mendapatkan pekerjaan. Pekerjaan dimaksud termasuk yang belum sesuai dengan kualifikasi atau latar belakang pendidikan. Atas dasar tersebut, kecenderungan yang muncul adalah lulusan perguruan tinggi lebih sebagai pencari kerja (jobseeker) daripada pencipta lapangan pekerjaan (job creator). Disamping itu, aktivitas kewirausahaan (Entrepreneurial Activity) yang relatif masih rendah. Entrepreneurial Activity diterjemahkan sebagai individu aktif dalam memulai bisnis baru dan dinyatakan dalam persen total penduduk aktif bekerja. Semakin tinggi indeks Entrepreneurial Activity maka semakin tinggi entrepreneurship level suatu negara (Boulton dan Turner, 2005).

Banyak faktor yang menimbulkan fenomena ini. Misalnya, sistem pembelajaran yang diterapkan di berbagai perguruan tinggi saat ini yang mungkin masih lebih terfokus pada bagaimana menyiapkan para mahasiswa yang cepat lulus dan mendapatkan pekerjaan, bukannya lulusan yang siap menciptakan pekerjaan. Hal lain adalah bahwa kemungkinan pembelajaran yang diajarkan di perguruan tinggi belum diarahkan kepada pengembangan wawasan yang berorientasi kepada kesiapan untuk menciptakan usaha yang dapat menjadikan mahasiswa setelah lulus untuk memiliki tingkat kemandirian tertentu.

Pada tahun anggaran 2009, Direktorat Jenderal Pendidikan Tinggi, Kementerian Pendidikan Nasional telah meluncurkan suatu program khusus bagi para mahasiswa yang disebut dengan Program Mahasiswa
Wirausaha (PMW). Program ini sebagai bagian dari strategi pendidikan di Perguruan Tinggi, dimaksudkan untuk memfasilitasi para mahasiswa yang mempunyai minat dan bakat kewirausahaan untuk memulai berwirausaha dengan basis ilmu pengetahuan, teknologi dan seni yang sedang dipelajarinya. Fasilitas yang diberikan meliputi pendidikan dan pelatihan kewirausahaan magang, penyusunan rencana bisnis, dukungan permodalan dan pendampingan usaha. Program ini diharapkan mampu mendukung visi-misi pemerintah dalam mewujudkan kemandirian bangsa melalui penciptaan lapangan kerja dan pemberdayaan UKM. Setidaknya ada enam tujuan utama PMW. Pertama menumbuhkan motivasi berwirausaha di kalangan mahasiswa. Kedua, membangun sikap mental wirausaha yakni percaya diri, sadar akan jati dirinya, bermotivasi untuk meraih suatu cita-cita, pantang menyerah, mampu bekerja keras, kreatif, inovatif, berani mengambil risiko dengan perhitungan, berperilaku pemimpin dan memiliki visi ke depan, tanggap terhadap saran dan kritik, memiliki kemampuan empati dan keterampilan sosial. Ketiga, meningkatkan kecakapan dan keterampilan para mahasiswa khususnya sense of business. Keempat, menumbuhkembangkan wirausahawirausaha baru yang berpendidikan tinggi. Kelima, menciptakan unit bisnis baru yang berbasis ilmu pengetahuan, teknologi dan seni. Keenam, membangun jejaring bisnis antarpelaku bisnis, khususnya antara wirausaha pemula dan pengu-saha yang sudah mapan. Alokasi dana PMW tidak seluruhnya untuk modal mahasiswa (Direktorat Jenderal Pendidikan Tinggi, 2009b).

Kementrian Pendidikan Nasional melalui Direktorat Jenderal Pendidikan Tinggi pada Tahun Anggaran 2009 mengalokasikan dana yang ditempatkan langsung pada DIPA PTN (Perguruan Tinggi Negeri) dan Kopertis (Kordinator Perguruan Tinggi Swasta). PTN yang termasuk dalam BHMN (Badan Hukum Milik Negara) diberikan dana sebesar Rp 2.5 M (dua setengah milyar); yang termasuk PTN non-BHMN masing-masing diberikan Rp 1 M (satu milyar); politeknik diberikan masing-masing sebesar Rp 500 juta (lima ratus juta rupiah); dan masingmasing Kopertis dialokasikan sebesar Rp 1 M (satu milyar). Khusus untuk Kopertis, dana dimaksud diberikan kepada Perguruan Tinggi Swasta (PTS) yang dipilih berdasarkan kriteria yang telah ditentukan. Alokasi dananya $70 \%$ diberikan pada mahasiwa 
dalam bentuk hibah dan alokasi yang 30\% diberikan kepada pengelola dalam hal ini perguruan tinggi (Direktorat Jenderal Pendidikan Tinggi, 2009b).

Mekanisme implementasi program mahasiswa wirausaha (PMW) ini adalah sebagai berikut: a) Perguruan tinggi pelaksana program melakukan sosialisasi kepada para mahasiswa; b) Perguruan tinggi melakukan identifikasi, seleksi mahasiswa, kemudian dilanjutkan dengan pembekalan kewirausahaan; c) Mahasiswa yang lolos seleksi melakukan penyusunan rencana bisnis sambil magang di sebuah UKM. Mahasiswa yang pernah mengikuti program magang kewirausahaan (Program Coop dan program kewirausahaan lain) dapat dibebaskan dari kewajiban magang. Untuk mendapatkan dukungan permodalan dalam rangka pendirian usaha baru (business startup) mahasiswa harus menyusun rencana bisnis yang layak. Kelayakan rencana bisnis ditentukan oleh tim penyeleksi yang terdiri dari unsur perbankan, UKM, dan perguruan tinggi pelaksana; d) Selama program berjalan perguruan tinggi bekerja sama dengan para pengusaha, baik UKM, koperasi maupun perusahaan besar memberikan bimbingan praktis wirausaha, mulai dari pendidikan dan pelatihan, magang, penyusunan rencana bisnis, dan pendampingan terpadu. Harus dihindari terjadinya persaingan yang tidak sehat antara mahasiswa dan UKM pendamping. Diperlukan terjadinya sinergi atau komplementaritas antara jenis usaha yang dikembangkan mahasiswa tersebut dan jenis usaha UKM pendamping. Pendirian usaha baru dapat dilakukan secara individual atau pun secara berkelompok dengan jumlah anggota maksimal 5 orang; dan e) Jumlah modal kerja yang disediakan untuk pendirian usaha maksimal Rp. 8.000.000,00 (delapan juta rupiah) per mahasiswa. Pelaksanaan pendampingan pasca magang dilakukan baik oleh UKM pendamping maupun Perguruan Tinggi pelaksana selama kurang lebih 9 bulan.

Tulisan ini merupakan kajian terhadap implementasi PMW (program mahasiswa wirausaha), khususnya untuk mengetahui sejauhmana program dan hibah yang diberikan memberikan dampak kepada mahasiswa. Dalam kaitan ini, kajian difokuskan pada: 1) pandangan mahasiswa penerima hibah terhadap adanya program ini; dan 2) pemanfaatan hibah oleh mahasiswa penerima.

\section{Kajian Literatur}

Gerakan membudayakan dan memasyarakatkan kewirausahaan sesungguhnya telah dicanangkan sejak tahun 1995 dengan diterbitkannya Inpres Nomor 4 Tahun 1995 tentang Gerakan Nasional Memasyarakatkan dan Membudayakan Kewirausahaan dimana Inpres dimaksud ditujukan kepada seluruh menteri dan gubernur (Salim Siagian dan Asfahani, 1997). Kelompok yang menjadi sasaran dari program pemasyarakatan dan pembudayaan kewirausahaan antara lain: 1) kelompok tertentu dalam masyarakat khususnya generasi muda pada umumnya anak sekolah/mahasiswa, anak putus sekolah, dan calon wirausahawan; 2) kelompok pengusaha yakni para pelaku ekonomi yang terdiri dari pengusaha mikro, kecil, menengah, dan koperasi; dan 3) kelompok Pembina, yang terdiri dari instansi pemerintah terkait, organisasi sosial dan nonpemerintah, lembaga pendidikan, organisasi pengusaha dan organisasi profesi. Adapun programprogram yang diusulkan untuk dilakukan pada saat itu meliputi antara lain pelatihan kewira-usahaan dan manajemen usaha kecil, bimbingan dan konsultasi bisnis, magang dan studi banding, bantuan pemasaran dan promosi, pengembangan teknologi tepat guna, bantuan permodalan, dan pengembangan kerjasama dan kemitraan.

Hasil survey Litbang Media Group yang ditulis dalam editorial Media Indonesia tanggal 30 April 2007 berjudul "Minimnya Minat menjadi Pengusaha" menunjukkan bahwa motivasi masyarakat Indonesia untuk menjadi pengusaha ternyata sangat rendah. Mayoritas responden menjawab lebih suka menjadi orang upahan alias pekerja daripada membuka usaha sendiri. Jajak pendapat tersebut sejalan dengan hasil Survei Tenaga Kerja Nasional 2001 hingga 2006, yang menyatakan bahwa profil tenaga kerja Indonesia memang dikuasai pekerja. Dari total pekerja 25 juta orang, jumlah yang menjadi pengusaha kurang dari seperlimanya. Terhadap pertanyaan dalam survey yang sama yaitu "mayoritas orang Indonesia ingin menjadi apa?" maka lebih dari $70 \%$ ingin menjadi pegawai negeri sipil (PNS). Yang menjawab ingin menjadi pengusaha hanya $20 \%$ saja. Angka ini jelas mencerminkan kondisi riil yang selama ini dirasakan.

Kewirausahaan sesungguhnya menunjuk pada semangat, sikap, dan perilaku sebagai teladan dalam keberanian mengambil resiko yang telah diperhitungkan berdasar atas kemauan dan kemampuan sendiri. Orang yang memiliki sikap-sikap tersebut dikatakan sebagai wiraswasta atau wirausaha 
(Sukidjo, 2011). Kewirausahaan menurut Suryana (2006) merupakan suatu disiplin ilmu yang memperlajari tentang nilai, kemampuan, dan perilaku seseorang dalam menghadapi tantangan hidup untuk memperoleh peluang dengan berbagai resiko yang mungkin dihadapinya. Dalam kewirausahaan terdapat kompetensi inti yaitu kreativitas dan inovasi dalam rangka menciptakan nilai tambah untuk meraih keunggulan denga berfokus pada pengembangan pengetahuan dan keunikan. Keterampilan, pengetahuan, dan kemampuan merupakan kompetensi inti wirausaha untuk menciptakan daya saing khusus agar memiliki posisi tawar menawar yang kuat dalam persaingan. Jiwa kewirausahaan dapat dibentuk melalui proses pembudayaan yang diintegrasikan dalam pembelajaran. Terdapat berbagai pandangan tentang karakteristik dan watak kewirausahaan.

Salah satu adalah seperti yang disampaikan oleh Meredith dalam Suharyadi, Arissetyanto Nugroho, Purwanto S.K dan Maman Faturohman (2007), yaitu bahwa terdapat 6 (enam) karakteristik wirausaha, yaitu 1) percaya diri; 2) berorientasi pada tugas dan hasil; 3) berani mengambil risiko; 4) kepemimpinan; 5) keorisinalan; dan 6) beorientasi masa depan. Karakter percaya diri dicirikan oleh watak dimana seseorang (wirausahawan) harus memiliki kepercayaan diri yang kuat dalam makna bahwa segala sesuatu yang telah diyakini dan dianggap benar harus dilakukan sepanjang tidak melanggar hukum dan norma yang berlaku. Percaya diri merupakan sikap dan keyakinan untuk memulai, melakukan, dan menyelesaikan tugas atau pekerjaan yang dihadapi. Berorientasi pada tugas dan hasil bercirikan bahwa seseorang (wirausahawan) harus fokus pada tugas dan hasil dan apapun pekerjaannya harus jelas apa hasilnya. Apabila usaha yang keras sudah dilakukan untuk jenis usaha tertentu dan ternyata tidak membuahkan hasil maka itu tidak ada gunanya. Apa yang dilakuka seorang wirausahawan merupakan usaha untuk mencapai tujuan yang telah ditentukan. Keberhasilan akan sangat ditentukan oleh motivasi berprestasi, berorientasi pada keuntungan, kekuatan dan ketabahan, kerja keras, enerjik, serta inisiatif. Berani mengambil risiko dicirikan oleh seseorang (wirausahawan) yang harus mengetahui peluang kegagalan (dimana sumber kegagalan dan seberapa besar peluang terjadi kegagalan) sehingga dapat memperkecil risiko. Karakter kepemimpinan dicirikan oleh seseorang (wirausahawan) yang dapat memberikan suri teladan, berpikir positif, tidak antikritik, dan memiliki kecakapan dalam bergaul. Kepemimpinan dimaksud bukan hanya memberikan pengaruh pada orang lain atau bawahannya, melainkan juga sigap untuk mengantisipasi setiap perubahan. Disamping itu mampu memimpin untuk melakukan perubahan dengan meluncurkan produk-produk baru lebih dulu, serta menjadi pelopor dalam penciptaan produk yang unggul atau memberikan nilai tambah yang berbeda dibandingkan para pesaing. Karakter keorisinalan dicirikan oleh hasil inovasi dan kreativitas yang diterapkan dimana seseorang (wirausahawan) harus bertindak dengan cara yang baru atau berpikir sesuatu yang lama dengan cara-cara yang baru. Karakter berorientasi pada masa depan dicirikan oleh seseorang (wirausahawan) yang terus berupaya untuk berkarya dengan menciptakan sesuatu yang baru dan berbeda dengan hasil yang sudah ada saat ini. Dengan demikian, seorang wirausahawan tidak cepat merasa puas dengan hasil yang diperoleh saat ini sehingga terus mencari peluang.

Sementara itu, Suharyadi, Arissetyanto Nugroho, Purwanto S.K dan Maman Faturohman (2007) mengidentifikasi sikap-sikap wirausahawan, sebagai: 1) disiplin; 2) komitmen tinggi; 3) jujur; 4) kreatif dan inovatif; 5) mandiri; dan 6) realistis. Disiplin diartikan sebagai ketepatan komitmen terhadap tugas dan pekerjaannya. Ketepatan yang dimaksud bersifat menyeluruh, diantaranya yaitu ketepatan terhadap waktu, mutu pekerjaan, dan sistem kerja. Komitmen tinggi diartikan dengan adanya komitmen yang jelas, terarah, dan bersifat progresif (berorientasi pada kemajun). Komitmen terhadap dirinya sendiri dapat dibuat dengan mengidentifikasi cita-cita, harapan, dan target-target yang direncanakan dalam hidupnya. Contoh komitmen tersebut adalah pelayanan prima yang berorientasi pada kepuasan komsumen, mutu produk yang sesuai dengan harga produk yang ditawarkan, serta pemecahan masalah bagi masalah konsumen. Sikap jujur yaitu antara lain menjaga karakteristik produk (barang dan jasa) yang ditawarkan, jujur terhadap promosi yang dilakukan, dan jujur mengenai pelayanan purnajual yang dijanjikan. Sikap kreatif dan inovatif dilandasi oleh cara berpikir yang maju dan penuh dengan gagasangagasan baru yang tidak dibatasi oleh ruang, bentuk, 
ataupun waktu. Sikap mandiri diwujudkan dengan melakukan keinginan dengan baik tanpa adanya ketergantungan pada pihak lain dalam mengambil keputusan atau bertindak, termasuk mencukupi kebutuhan hidupnya. Sikap yang terakhir yaitu realistis dimaknai sebagai seseorang yang mampu menggunakan fakta atau realita sebagai landasan berpikir yang rasional dalam setiap pengambilan keputusan maupun tindakan atau perbuatannya.

Panji Anoraga dan Djoko Sudantoko (2002) menyatakan adanya 5 (lima) esensi pokok kewirausahaan. Kelima esensi pokok tersebut yaitu: 1) kemauan kuat untuk berkarya dengan semangat kemandirian (terutama dalam bidang ekonomi); 2) kemauan memecahkan masalah dan membuat keputusan secara sistematis, termasuk keberanian mengambil resiko usaha; 3 ) kemauan berpikir dan bertindak secara kreatif dan inovatif; 4) kemauan bekerja secara teliti, tekun dan produktif; dan 5) kemauan berkarya dalam kebersamaan berlandaskan etika bisnis yang sehat. Lebih lanjut, Panji Anoraga dan Djoko Sudantoko (2002) mengatakan bahwa wirausaha sejati akan memiliki kemampuankemampuan dan sikap-sikap khas. Kemampuan dimaksud, yaitu: 1) melihat peluang, selalu berusaha memanfaatkan kesempatan baik; 2) melihat masa depan dan memiliki perencanaan yang tepat; 3) mendapatkan informasi serta meman-faatkannya untuk kemajuan perusahaan; dan 4) memimpin orang banyak. Sikap-sikap tersebut meliputi: 1) memiliki rasa tanggungjawab; 2 ) selalu dinamis, ulet dan canggih, tidak cepat menyerah karena sadar untuk mencapai kemajuan memerlukan kerja keras; 3) berani menerima kritik dan saran yang bermanfaat; dan 4) berinisiatif untuk maju dan melakukan yang terbaik untuk mencapai keberhasilan.

Dari berbagai teori dan pendapat akademisi maupun praktisi sebagaimana diuraikan sebelumnya, dapat disimpulkan bahwa kewirausahaan akan melibatkan pembentukan sikap/pola pikir (attitude), pengembangan keterampilan (skill), dan pembekalan pengetahuan (knowledge). Untuk mewujudkan halhal tersebut diperlukan proses kreatif dan inovatif dalam melihat atau menciptakan peluang dan merealisasikannya, dengan memperhatikan segala risiko, menjadi sesuatu yang bernilai. Yang menarik adalah bahwa keberadaan seorang wirausaha tidak saja karena memang memiliki keturunan atau bakat sejak lahir, tetapi juga dapat terjadi karena lingkungan dan latihan. Program Mahasiswa Kewirausahaan (PMK) pada dasarnya merupakan suatu alternatif untuk menjadikan mahasiswa sebagai wirausaha melalui proses pelatihan dengan memperhatikan berbagai kesempatan dan peluang yang ada di lingkungannya. PMK juga menjadi suatu media untuk menjadikan mahasiswa berupaya untuk mencari dan mengenali perubahan-perubahan yang terjadi dengan keinginan untuk merespons perubahan tersebut menjadi kesempatan atau peluang melalui keberanian melakukan eksplorasi yang penuh resiko kegagalan. Keberhasilan program ini dapat diukur apabila mahasiswa dapat memanfaatkan hibah yang diterimanya untuk menjadikan peluang-peluang yang ada dalam lingkungan kampus atau daerahnya menjadi suatu produk yang bernilai yang berbeda dan tidak mudah ditiru pesaing lainnya, yang kemudian bisa dimanfaatkan secara komersial dengan kapabilitas yang ada, serta diminati oleh berbagai pelanggan.

\section{Metodologi}

Data yang digunakan dalam kajian ini merupakan data primer yang bersumber dari para mahasiswa penerima hibah PMW pada tahun anggaran 2009. Pemilihan mahasiswa sebagai pembahan (responden) dalam kajian ini dilakukan secara acak, yaitu mereka yang selama ini: 1) memiliki komunikasi dan interaksi dengan pihak Direktorat Jenderal Pendidikan Tinggi; 2) pernah menjadi narasumber pada berbagai pertemuan yang dilakukan oleh Direktorat Jenderal Pendidikan Tinggi; dan 3) masih meneruskan usaha wirausahanya sampai kajian ini dilakukan.

Mahasiswa yang menjadi responden yaitu 1 (satu) orang berasal dari Institut Pertanian Bogor (IPB), 2 (dua) orang berasal dari Universitas Brawijaya (UB) Malang, satu tim yang terdiri dari 4 (empat) mahasiswa dari Unversitas Udayana (Unud) Bali, dan satu mahasiswa dari STIE Perbanas Surabaya. Untuk memperoleh data dimaksud, dilakukan wawancara dan interaksi melalui imel (email). Pertanyaan yang diajukan, yaitu: (1) pandangan mereka terhadap PMW, (2) pemanfaatan terhadap hibah yang diberikan, dan (3) kinerja yang telah dicapai mereka sebagai penerima hibah. Jawaban pembahan kategori ini dirumuskan dalam bentuk testimoni. 


\section{Hasil dan Pembahasan \\ Hasil}

Pada bagian ini dipaparkan tanggapan pembahan mahasiswa penerima hibah PMW dalam bentuk testimoni. Testimoni dimaksud berisikan antara lain deskripsi singkat mengenai usaha atau bisnis yang dilakukan, proses ketika yang bersangkutan mengikuti seleksi di perguruan tinggi masingmasing, dan keberhasilan usaha atau bisnis yang dilakukan dengan merujuk kepada modal awal yang diperoleh dari PMW ini. Perumusan dan penulisan testimoni merupakan bahasa asli yang ditulis dari mahasiswa penerima yang diedit untuk memperjelas makna dari kalimat-kalimat yang ditulis.

\section{Testimoni bisnis "Anperindo Farm"}

Pendiri dari bisnis Anperindo Farm adalah Ance Trio Marta. Ance merupakan mantan mahasiswa dari IPB. Secara umum, Ance menyatakan bahwa program mahasiswa wirausaha memberikan kemanfaatan kepada upaya pengembangan jiwa kewirausahaan bagi mahasiswa. Dikatakannya bahwa usahanya bermula pada tahun 2009 ketika dia berhasil meyakinkan Direktorat Pengembangan Karir dan Hubungan Alumni untuk membantu mendampingi usaha dan memberikan bantuan modal. Bantuan modal dimaksud diperolehnya dari Program Mahasiswa Wirausaha (PMW), yang kemudian digunakan untuk mengembangkan usaha dengan memperbanyak indukan bawal.

Menurut Ance, keikutsertaan dalam PMW ini membuka peluang pengembangan usaha. Salah satu di antaranya yaitu mengantarkan Ance menjadi pemenang juara pertama Wirausaha Muda Mandiri untuk katagori industri dan jasa tahun 2009. Saat ini, Ance menjelma menjadi praktisi bisnis yang professional. Tidak hanya mengembangkan bisnis budidaya bawal tetapi juga menjadi trainer dan pembicara di berbagai forum dan berbagai tempat. Keuntungan bersih per bulan saat ini mencapai 2024 juta rupiah per bulan dan mempekerjakan 6 orang karyawan dengan sistem gaji permanen dan 10 orang karyawan tidak tetap. Kini dia mempunyai plasma 12 orang dan petani larva 25 orang di sejumlah wilayah di Jawa Barat. Kisah Ance terasa manis dan mudah diikuti. Namun, sebelum mengikuti jejaknya, ingat bahwa dia pernah gagal berkali-kali.

Testimoni lengkap Ance yaitu sebagai berikut:
Program Mahasiswa Wirausaha sangat baik dan melatih secara aplikatif kegiatan berwirausaha di kampus. Oleh karena itu perlu penambahan supaya semakin banyak mahasiswa yang terlibat dalam kegiatan ini. Dari program ini saya mendapatkan relasi dan pengetahuan yang baik tentang kewirausahaan, mengerti tentang kendala dan masalah untuk maju dalam berwirausaha dan mengetahui bagaimana menjadi seorang wirausaha sejati. Setelah lulus saya ingin berwirausaha dengan mempekerjakan banyak orang orang yang tidak lulus kuliah, tidak lulus sekolah dan lainnya dan menciptakan lapangan kerja yang lebih banyak dengan konsentrasi pada komoditi yang saya usahakan.

\section{Testimoni bisnis "Chicksmart"}

Hikmah Prahadian yang menjadi pemilik dari bisnis Chicksmart, merupakan lulusan S1 Program Studi Teknologi Hasil Ternak, Fakultas Peternakan, Universitas Brawijaya. Chicksmart merupakan usaha yang berbasis pada produk makanan yang berbahan pokok daging ayam. Produk yang dibuat adalah nugget ayam dan bakso ayam dengan isi yang bervariasi (keju, sayur, dan lain-lain) dimana proses pembuatannya menggunakan bumbu dan bahan segar serta tanpa bahan pengawet.

Hikmah memberikan testimoni tentang PMW sebagai berikut:

Program ini menurut saya program yang positif, baik, berguna dan menyenangkan. Dengan program ini saya belajar cara memulai untuk berwirausaha, menjadi seorang pemimpin serta manajemennya. Pada dasarnya saya sangat senang dengan wirausaha, karena dalam pandangan saya, orang yang berwirausaha akan mempunyai kepuasan sendiri, selain itu dapat meningkatkan pengetahuan karena seorang wirausaha akn terus mempelajari dan selalu berfikir ke depan untuk mengembangkan usahanya serta meningkatkan kualitasnya. Ucapan terima kasih saya haturkan kepada seluruh panitia PMW yang telah memberikan fasilitas berupa pelatihan, workshop serta pertemuan-pertemuan dengan pemilik UKM se Jawa Timur. Ucapan terima kasih juga saya haturkan kepada DIKTI karena telah mencetuskan program ini dan memberikan dana yang berfungsi sebagai modal berwirausaha. 
Konsep dari PMW sangat bagus menurut saya, karena dana yang diberikan oleh Dikti tidak hanya diberikan secara cuma-cuma, namun dana PMW diberikan dengan sebuah pembelajaran yang berwirausaha, dengan hal ini akan membuat mahasiswa lebih kreatif, inovatif, mandiri, dan bekerja keras untuk mewujudkan kesuksesan usaha yang ditekuninya. PMW juga dapat memberikan kesempatan kepada kami untuk ber-silaturahmi dengan orang-orang sukses, bertemu dengan pengusaha lainnya sehingga dapat menambah relasi dan saling bekerjasama. Selain itu PMW juga dapat menghantarkan saya berangkat ke kantor DIKTI dan bertemu dengan orang-orang sukses seperti Bob Sadino, Sandiaga Uno, Ciputra dan lain-lain, karena pada saat itu saya adalah salah satu perwakilan dari Universitas Brawijaya untuk menghadiri undangan DIKTI di Jakarta.

\section{Testimoni bisnis "Toko Pupuk Online"}

Elsa Rosyidah mendapatkan hibah PMW ketika masih menjadi mahasiswa Keteknikan Pertanian Fakul-tas Teknoogi Pertanian Universitas Brawijaya. Pada saat itu Elsa mengajukan proposal perorangan dimana setelah melalui proses seleksi yang ketat proposalnya dinyatakan diterima dan berhak memperoleh hibah sebesar Rp 8 juta (delapan juta rupiah). Berikut merupakan testimoni Elsa Rosyidah tentang PMW:

Kami sangat apresiatif dengan komitmen, perhatian dan upaya nyata panitia PMW UB untuk memfasilitasi perkembangan wirausaha muda di Universitas Brawijaya. Eksisitas PMW ini harus dikembangkan dan terus dilanjutkan sebagai stimulan lahirnya mahasiswa wirausahawirausaha muda yang berkontribusi terhadap ketahanan ekonomi nasional. Saya sangat merekomendasikan bagi teman-teman mahasiswa Indonesia untuk mengambil kesempatan emas ini dengan bergabung bersama PMW. Berikut yang teman-teman peroleh dengan ikut PMW, yaitu: 1) dana modal, digunakan sebagai start-up capital untuk bisnis gagasan kita; 2) monitoring, dukungan pendampingan dari dosen/panitia PMW; 3) relasi, banyak teman banyak rejeki; dan 4) atmosfir wirausaha, ini yang paling penting dan sukar dibeli dengan uang. Lingkungan wirausaha dari teman dan mentor akan menjaga komitmen dan membantu kita untuk terus melangkah di dunia wirausaha.

Informasi mengenai usaha yang dijalankan Elsa yaitu Toko Pupuk Online ini dapat diakses di http://tokopupuk.net dan http://tokopupuk. blogspot.com. Usaha ini merupakan industri jasa yang memfokuskan diri di bidang pemasaran melalui media internet. Toko pupuk online mengintegrasikan antara pengetahuan budidaya pertanian, manajemen industri, teknik lingkungan, website, excellent costumer service, dan internet marketing. Usaha ini berkantor dunia nyata di Malang, Jawa Timur. Berbekal 8 (delapan) juta rupiah dari PMW dan modal pribadi, pada akhir tahun 2009 Toko Pupuk Online mencatat pembukuan dengan capaian omset Rp 157.527.500,- dan profit Rp 24.205.100,-.

Menarik untuk mencermati cerita Elsa tentang awal mula dan tantangan Toko Pupuk Online. Dikatakan bahwa proposal awal PMW yang diajukan sebenarnya tidak berisi pemasaran pupuk. Pada awal wirausaha PMW, yang dikerjakan adalah internet marketing berupa jasa iklan website google adsense. Dalam per-jalanannya, mahasiswa pengusaha ini ditawari oleh pemilik CV. Dewi Sri Rama untuk memasarkan pupuk secara online agar jangkauan pasar lebih luas. Pada tahap awal, Elsa hanya membantu dengan mencoba-coba memasarkan pupuk menggunakan web gratis berupa blog yakni http://tokopupuk.blogspot.com dan memasarkan keberadaan blog toko pupuk menggunakan internet marketing. Tanpa diduga dalam waktu 10 hari setelah blog terpasang, ada permintaan pupuk 8 ton dari Surabaya untuk dikirim ke Medan. Sejak itulah kami bergeser dari google adsense menuju toko pupuk online.

Tantangan dalam membangun dan mengembangkan toko pupuk online adalah bagaimana cara menarik pengunjung agar berkunjung ke website toko pupuk online untuk meningkatkan kunjungan website (traffic). Toko pupuk online di dunia maya harus bersaing dengan jutaan website. Oleh sebab itu toko pupuk online menggunakan pengetahuan internet marketing untuk meningkatkan pengunjung website. Strategi terbesar internet marketing adalah Search Engine Optimize (SEO) yaitu optimalisasi website didalam mesin pencari (search engine) seperti Google, Yahoo dan MSN. Sebab potensi terbesar kunjungan ke website toko pupuk online 
berasal dari mesin pencari.

\section{Testimoni bisnis "Statistic Center"}

Mahasiswa penerima hibah PMW ini yaitu Ferry Angga Irawan, merupakan lulusan Universitas Brawijaya. Usaha Ferry yang disebut "Statistics Center" merupakan suatu lembaga yang bergerak di bidang jasa konsultasi dan analisis data statistika. Usaha ini pada awalnya dikerjakan bersama beberapa mahasiswa. Keputusan mereka untuk memulai usaha ini didasarkan atas hasil survey yang telah dilakukan pada beberapa mahasiswa, dimana $75 \%$ responden menyatakan bahwa statistika itu sulit dan cukup mahalnya biaya untuk melakukan analisis data pada beberapa tempat yang menyediakan jasa analisis data di kota Malang. Pendirian lembaga ini diharapkan mampu membantu menyelesaikan masalah-masalah yang ada khususnya dalam hal penelitian baik dari akademisi, instansi pemerintah maupun swasta. Berdasarkan penjabaran segmentasi diatas, mahasiswa pengusaha ini mengerucutkan pilihan pada segmen akademisi/mahasiswa dikarenakan cakupan pasarnya yang cukup besar.

Secara khusus Statistic Center memiliki 3 (tiga) tujuan, yaitu: 1) membantu dan membimbing mahasiswa dalam memahami permasalahanpermasalahan statistika dalam suatu penelitian; 2) memberikan jasa analisis data untuk memudahkan mahasiswa memahami data hasil penelitian; dan 3) memberikan jasa pelatihan software statistika sehingga dapat membantu mahasiswa dalam mengoperasikan software sehingga mampu menganalisis data sendiri nantinya.

Setelah menerima bantuan sebesar 8 juta rupiah dari program mahasiswa wirausaha (PMW) tahun 2009 oleh Direktorat Jenderal Pendidikan Tinggi, langkah pertama yang dilakukan adalah membeli sarana dan prasarana yang menunjang dalam proses analisis data yaitu laptop dan printer. Di samping itu, dibuat media promosi berupa spanduk, pamflet, leaflet, kartu nama dan sebuah blog. Sebagai kantor (base-camp) pada tahap awal digunakan rumah kontrakan salah satu anggota dengan pertimbangan bahwa masih belum ada dana yang cukup untuk menyewa tempat sendiri. Yang paling prioritas bagi pengusaha mahasiswa ini adalah bagaimana caranya bisa mendapatkan klien baru dan untuk tempat bisa memanfaatkan tempat kontrakan dan perpustakaan kampus.
Dalam waktu 3 (tiga) bulan pertama, sudah diperoleh klien (client) rata-rata tiap bulan sekitar 5 - 10 orang. Untuk dapat meningkatkan jumlah klien, Ferry Angga Irawan bekerjasama dengan rental-rental komputer yang ada di dekat kampus. Dalam waktu singkat, telah berhasil dilakukan kerjasama dengan 6 tempat rental komputer, dimana sekaligus didapatkan klien baru yang berasal dari rental-rental tersebut. Untuk setiap klien yang berasal dari rental tersebut dilakukan bagi hasil. Beberapa waktu berikutnya sudah bisa didapatkan klien rata-rata tiap bulan sebanyak 10 - 20 orang.

Seiring berjalan dengan waktu ditemukan beberapa kendala yaitu ketidakfokusan dari tim dalam menjalankan dan mengembangkan usaha ini, karena memang pendapatan yang didapatkan pada saat itu masih belum bisa mencapai gaji UMR, sehingga bagi anggota yang pada saat itu sudah tidak mendapat bantuan biaya dari orang tua harus mencari pemasukan lain. Hal ini cukup menyebabkan terganggunya proses kerja dari tim. Namun motivasi yang kuat dari pribadi Ferry yaitu bahwa usaha ini pasti bisa terus dikembangkan membuat dirinya tetap berusaha untuk fokus dan menjalankannya sendiri hingga kini. Menurut Ferry, keuntungan menjalankan usaha ini sendiri yaitu bahwa dia lebih leluasa dalam melakukan pengembangan yaitu dengan memaksimalkan proses kerjasama antara dirinya dengan rental yang sudah diajak bermitra. Kenyataan bahwa tempat rentalrental tersebut cukup strategis dan sudah sering didatangi oleh konsumen maka secara otomatis bisnis Statistic Center juga ikut terbantu pada promosinya. Pada saat ini, klien bisnis Statistic Center rata-rata tiap bulannya menjadi 20 - 40 klien.

\section{Testimoni bisnis "Dharma Sasmita"}

Bisnis "Dharma Sasamita" merupakan inisiatif dari 4 (empat) mahasiswa Universitas Udayana di Denpasar, Bali yang didirikan pada tanggal 8 Juli 2009. Keempat angggota pendiri adalah Gusti Ayu Novaeni, Dwi Mahendra Putra, Ni Made Ari Dwijayanti, Wayan Yogik Aditya Urdhahana. Dharma Sasmita menciptakan produk yang dapat membantu masyarakat dalam mempelajari Aksara Bali. Produk itu bernama

Kunci Aksara. Kunci aksara ini merupakan media pembelajaran dasar mengenai aksara Bali. Kunci Aksara ini menggunakan media pembelajaran yang 
lebih inovatif, selain dapat digunakan dalam proses belajar pembelajaran, produk ini dapat pula digunakan untuk bermain. Produk Kunci Aksara ini dapat membantu orang tua untuk membimbing putraputrinya mempelajari Aksara Bali.

Alasan pemilihan produk ini adalah karena Aksara Bali cenderung dianggap sulit dan menakutkan bagi anak-anak pada khususnya. Kesulitan itu semakin tinggi karena orang tua tidak mempunyai waktu untuk membimbing dan mengajarkan putraputrinya karena terlalu sibuk dengan pekerjaanya. Selain kesibukan orang tua dalam berkarir serta ditambah dengan keterbatasan pengetahuan dan pengalaman orang tua dalam bidang bahasa, aksara, dan sastra Bali. Produk Kunci Aksara terdiri atas 2 bentuk, yakni kartu Aksara dan poster dengan menggunakan beberapa software grafis serta didukung dengan font Aksara Bali atau lebih dikenal dengan font Bali Simbar. Metode yang digunakan dalam produk ini ialah metode belajar sambil bermain, sehingga bahasa Bali yang terkesan menyulitkan dapat dihilangkan. Dengan kemudahan itu orang tua akan lebih mudah untuk mengajarkan putra-putrinya memahami Aksara Bali.

Produk Kunci Aksara selain merupakan produk industri kreatif, juga merupakan salah satu implementasi dari program pemerintah Daerah maupun pemerintah Pusat, dan juga mendukung progam unggulan Universitas Udayana. Program tersebut antara lain: Keberadaan Universitas Udayana sebagai salah satu perguruan tinggi di Bali memiliki peranan penting sebagai wadah pelestarian bahasa, sastra, dan kebudayaan Bali dengan pola ilmiah pokok adalah kebudayaan. Hal ini sejalan dengan program yang dicanangkan Rektor Universitas Udayana dalam rangka Universitas Udayana menuju universitas kelas dunia (World Class University).

Kunci Aksara ini telah diluncurkan (launching) di Fakultas Sastra Universitas Udayana pada tanggal 28 Agustus 2009 serangkaian dengan HUT Fakultas Sastra yang ke-51. Tidak hanya sebatas launching saja, Dharma Sasmita beserta dengan peserta PMW yang lain telah melakukan pameran Produk serangkaian dengan Dies Natalis Universitas Udayana pada tahun 2009. Pada tanggal 14 November 2009, Dharma Sasmita telah melaksanakan Seminar Aksara Bali bekerja sama dengan Laboraturium Nyastra Fakultas Sastra Universitas Udayana dengan tema
"Industri Kreatif Aksara Bali Berbasis Teknologi Informatika" yang melibatkan 118 orang dari kalangan Guru SD/SMP se Kabupaten Badung dan Denpasar. Dosen Pendidikan Bahasa Bali di Perguruan Tinggi Negeri/Swasta Se-Bali, Mahasiswa, Komunitas Kreatif.

Kunci Aksara merupakan salah satu industri kreatif yang berlandaskan atas budaya. Dengan adanya suatu usaha yang memanfaatkan industri kreatif diharapkan nantinya dapat menghasilkan imbas yang positif berupa budaya kreatif. Budaya merupakan aspek yang dapat dijadikan sebagai sumber untuk membuka lapangan kerja, melestarikan budaya dan budaya memiliki nilai tambah dalam kehidupan masyarakat.

Dharma Sasmita sampai saat ini telah dapat menjual 150 produknya dari 500 paket dengan harga Rp 40.000/paket dan 25 poster dari 200 poster yang dibuat dengan harga Rp. 30.000/ poster. Produk ini mengalami kesulitan dalam pemasarannya akibat aturan birokrasi untuk masuk ke sekolah-sekolah yang cukup sulit. Sehingga membutuhkan pendekatan yang lebih prepentif. Pendekatan preventif juga dibutuhkan dikalangan masyarakat, sehingga kedepanya produk ini dapat terjual lebih banyak. Produk ini sangatlah berguna untuk membantu masyarakat, Kunci Aksara merupakan salah satu industri kreatif yang berlandaskan atas budaya. Dengan adanya suatu usaha yang memanfaatkan industri kreatif diharapkan nantinya dapat menghasilkan imbas yang positif berupa berupa budaya kreatif.

Ditinjau dari wilayah pemasaran yang sesuai rencana hanya dipasarkan di wilayah Denpasar, namun dalam perjalanannya telah mampu melebihi target yakni telah menjangkau wilayah Denpasar, Badung dan Negara. Dilihat dari kegunaan, produk ini sangatlah berguna untuk membantu masyarakat. Kunci Aksara ini terbukti efektif untuk diterapkan demi meningkatkan kemampuan siswa didalam memahami aksara Bali terbukti dengan setelah dilaksanakan pengajaran ini, salah seorang dari peserta pelatihan program pengajaran aksara Bali berhasil meraih juara III dalam rangka lomba nyurat aksara Bali tingkat gugus.

Usaha ini merupakan implementasi dari usaha pemerintah dalam pelestrarian kebudayaan daerah, baik pemerintah pusat maupun pemerintah daerah. Karena dengan usaha ini diharapkan keaneka- 
ragaman kebudayaan daerah yang dimiliki oleh bangsa Indonesia dapat menunjang kebudayaan Nasional. Produk ini baru dapat dinikmati oleh masyarakat Bali pada khususnya dan warga negara Indonesia pada umumnya. Karena produk ini baru menggunakan bahasa Indonesia dan aksara Bali. Kedepannya kami merencanakan produk ini dapat masuk ke pasar Internasional dengan cara merancang cara penggunaan Kunci Aksara ini dengan menggunakan bahasa pengantar Trilingual yakni menggunakan Bahasa Indonesia, Bali dan Inggris. Sehingga kebudayaan Bali lebih dikenal di dunia Internasional dan semakin dicintai oleh masyarakatnya. Tentunya untuk mencapai tujuan itu diperlukan dana, oleh sebab itu kami memohon bantuan dana dari semua pihak demi terciptanya tujuan itu, sebagai salah satu implementasi Indonesia yang Adi Budaya.

\section{Testimoni bisnis "Smart Magic Card"}

Pendiri bisnis ini adalah seorang mahasiswa dari STIE-Perbanas di Surabaya yang bernama Rianto Prasetyo Wibowo. Menurut mahasiswa pengusaha ini, bisnis "Smart Magic Card" sebagai alat bantu belajar berawal dari keisengan mengamati alat judi "roller" dan cara kerja primbon Jawa. Alat ini mengusung tema education-entertainment (Edutainment). Seperti dikatakan Rianto, pada awalnya memang agak "ogah-ogahan" dalam membuat desain dan rencana pengembangan. Namun, setelah mengikuti beberapa kali kompetisi proposal bisnis, akhirnya yang bersangkutan semakin mantap untuk menekuni usaha ini. Hal ini tidak terlepas dari banyaknya apresiasi positif yang diperoleh baik dari rekan-rekan maupun para dewan juri lomba. Berita yang paling menggembirakan ialah pada bulan Agustus 2009, ide bisnis ini berhasil meraih juara I dalam Young Entrepreneur Award 2009.

Sebagaimana dijelaskan oleh Rianto, sampai sejauh ini, "Smart Magic Card" sudah mulai merambah wilayah Surabaya, Sidoarjo dan sekitarnya. Pola pemasaran yang dilakukan adalah dengan menggunakan sistem keagenan, direct-selling dan konsinyasi. Dalam mendukung sistem konsinyasi, dilakukan kerjasama dengan beberapa toko buku yang sudah dikenal oleh masyarakat. Omzet bulanan dari usaha ini memang belum stabil, dimana setiap bulannya bisa menghasilkan antara Rp 750.000 sampai dengan Ro 1.400.000. Adanya Program Mahasiswa Wirausaha (PMW) pada tahun 2009, memperkuat Rianto untuk melanjutkan bisnisnya karena diperoleh bimbinganbimbingan untuk mengembangkan usaha "Smart Magic Card" ini. Selain itu, dengan mengikuti PMW, diperoleh banyak relasi bisnis. Berikut adalah testimoni dari Rianto Prasetyo Wibowo

Bagi kami, PMW bukan hanya sekadar Program Mahasiswa Wirausaha melainkan sebuah Process to Mind the World karena dampak dari program ini sangat luar biasa. Program ini mampu menjadi wadah dalam membuka jalur bagi mahasiswa yang ingin berwirausaha. Selain mendapatkan kucuran dana dari DIKTI untuk merealisasikan proposal bisnis tersebut, kami juga memperoleh pelatihan-pelatihan kewirausahaan yang sangat mendukung langkah kami. Dengan demikian, Program Mahasiswa Wirausaha patut mendapatkan apresiasi dari semua pihak dan sangat layak untuk dijadikan sebagai program regular bagi Pendidikan Tinggi mengingat manfaatnya yang begitu besar. Kami yakin bahwa program ini mampu memuluskan langkah Pemerintah untuk menumbuh kembangkan entrepreneurship di Indonesia sehingga lulusan Perguruan Tinggi akan benar-benar menjadi agen perubahan untuk menciptakan lapangan kejera. Pada akhirnya, kemakmuran secara ekonomi akan segera terwujud

\section{Pembahasan}

Data yang ada pada Direktorat Jenderal Pendidikan Tinggi (2009c) menunjukkan bahwa perguruan tinggi yang terlibat dalam program ini pada tahun anggaran 2009 berjumlah 82 Perguruan Tinggi Negeri (PTN) yang berarti seluruh PTN (100\%) dan 179 dari 2.600 atau $7 \%$ dari seluruh Perguruan Tinggi Swasta (PTS). Jumlah dana yang dialokasikan untuk kegiatan PMW mencapai Rp113.000.000.000,00 (seratus tiga belas milyar rupiah). Data dimaksud juga menunjukkan jumlah mahasiswa di berbagai perguruan tinggi tersebut yang mendapatkan bantuan dana PMW. Tercatat sejumlah 8.296 orang mahasiswa yang terlibat dalam PMW dengan rincian 6.779 mahasiswa (82 \%) berasal dari PTN dan 1.517 mahasiswa (18 $\%$ ) berasal dari PTS. Dengan jumlah tersebut berarti rata-rata mahasiswa yang terlibat berjumlah 36 orang per perguruan tinggi.

Meskipun responden dari kajian ini masih sangat terbatas, pengakuan atau testimoni para responden dapat menjadi indikasi positif tentang kebijakan PMW 
(Program Mahasiswa Wirausaha). Kebijakan ini dapat dianggap sebagai salah satu terobosan sekaligus sebagai salah satu alternatif instrumen untuk mengurangi tingginya angka pengangguran dari lulusan-lulusan pendidikan tinggi. PMW memberikan beberapa manfaat yang cukup strategis. Pertama, kebijakan ini dapat menjadi sumber pendapatan bagi para calon pengusaha yang berasal dari mahasiswa yang pada akhirnya akan menciptakan kemandirian tertentu. Kedua, para mahasiswa calon pengusaha ini menciptakan kesempatan kerja bagi masyarakat yang berada di sekitar lokasi usaha mereka baik sebagai mitra maupun sebagai pekerja dalam usahausaha yang dijalankan. Hal ini dapat dijelaskan dengan menggunakan data tentang peserta PMW.

Penciptaan peluang kerja melalui PMW dapat diterangkan dengan menggunakan asumsiasumsi. Misalnya, dari seluruh mahasiswa peserta PMW hanya sekitar $10 \%$ yang dapat melanjutkan usahanya; dan dari setiap mahasiswa dalam kelompok $10 \%$ tersebut dapat mempekerjakan sekitar 2-3 orang. Dengan demikian, jumlah lapangan pekerjaan yang dapat dibuka oleh PMW dalam arti jumlah orang yang terlibat adalah sebanyak 2490 orang. Angka tersebut didapat dari mengalikan 830 mahasiswa yang melanjutkan usaha (10\% dari 8.296 mahasiswa) dengan pegawai atau orang yang dipekerjakan di setiap usaha yaitu masing-masing 3 orang. Angka penciptaan lapangan pekerjaan tersebut akan menjadi lebih besar apabila jumlah mahasiswa peserta PMW yang masih aktif tidak hanya sekadar $10 \%$ dari total mahasiswa PMW.

Dari testimoni beberapa mahasiswa penerima bantuan PMW terlihat bahwa esensi pokok kewirausahaan sesungguhnya sudah mulai menjadi pola pemikiran pada mahasiswa-mahasiswa. Walaupun baru dalam tahap-tahap awal, para mahasiswa tersebut telah memiliki beberapa ciri-ciri seorang wirausaha yaitu di antaranya memiliki kemauan kuat untuk berkarya dengan semangat kemandirian, memecahkan masalah dan membuat keputusan secara sistematis, termasuk keberanian mengambil resiko usaha, berpikir dan bertindak secara kreatif dan inovatif, bekerja secara teliti, tekun dan produktif, serta berkarya dalam kebersamaan berlandaskan etika bisnis yang sehat.

Di samping itu, testimoni di atas cenderung menunjukkan kemampuan khas seorang wirausaha sejati sebagaimana diungkapkan oleh Panji Anoraga dan Djoko Sudantoko (2002), baik dari aspek kemampuan maupun sikap. Contoh sederhana yaitu dari apa yang direfleksikan oleh Ferry Angga Irawan dengan bisnis "Statistic Center" nya. Mahasiswa tersebut telah mampu melihat peluang dan selalu berusaha memanfaatkan kesempatan baik tercermin dalam bentuk keputusan untuk memulai usaha dengan melakukan survey atau melakukan analisis situasi tentang apa yang diperlukan di sekitarnya. Sedangkan sikap-sikap khas wirausaha sejati yang sudah ditunjukkan oleh Ferry yaitu tetap melanjutkan usahanya walaupun anggota-anggota kelompoknya mengundurkan diri atau dalam bahasa yang dituliskan Ferry yaitu "ketidakfokusan". SIkap tersebut paling tidak sudah merefleksikan 2 (dua) dari sikap-sikap wirausaha sejati seperti yang dikatakan oleh Panji Anoraga dan Djoko Sudantoko (2002), yaitu memiliki rasa tanggungjawab; selalu dinamis, ulet dan canggih, tidak cepat menyerah karena sadar untuk mencapai kemajuan memerlukan kerja keras.

Cerminan dari kemampuan dan sikap-sikap mahasiswa penerima bantuan PMW tersebut sekaligus sebagai suatu indikator keberhasilan dari program ini yaitu setidak-tidaknya mengubah pola pikir (mind-set). Testimoni para responden sesungguhnya menjadi bukti bahwa mahasiswa dapat berperan serta secara aktif dalam proses perekonomian sekaligus dalam proses untuk tidak menjadi beban masyarakat manakala mereka menyelesaikan studi di perguruan tinggi. Kemampuan dan sikap yang ditunjukkan tersebut setidak-tidaknya memberikan optimisme ke depan bahwa terobosan Pemerintah melalui PMW memberikan kontribusi yang nyata. Ukuran keberhasilan program ini tentu saja dapat didasarkan atas keberhasilan atau capaian mereka dalam bentuk nominal penghasilan maupun omzet perusahaan yang dirintis. Dari pengakuan responden, ternyata bantuan hibah yang relatif tidak begitu besar telah berhasil mereka gandakan berlipatlipat dalam proses waktu yang relatif singkat yaitu bahkan tidak lebih dari setahun perkuliahan.

\section{Simpulan dan Saran Simpulan}

Kebijakan Program Mahasiswa Wirausaha (PMW) menjadi suatu instrumen yang cukup efektif untuk mengubah pola pikir mahasiswa. Kebijakan ini memotivasi mahasiswa untuk berani mengambil 
suatu keputusan dan menjadi peduli terhadap berbagai permasalahan yang ada di lingkungannya untuk mencari alternatif solusi yang bermanfaat bagi diri pribadi dan juga masyarakat sekitar.

Kebijakan Program Mahasiswa Wirausaha (PMW) dapat menjadi suatu alternatif terhadap permasalahan bangsa yaitu untuk mengurangi angka pengangguran dari lulusan perguruan tinggi. Munculnya calon-calon pengusaha dari kelompok mahasiswa menjadi bukti keberhasilan kebijakan PMW ini karena kemudian ketika lulus mereka tidak lagi menjadi pencari kerja yang menjadi beban masyarakat dan negara, tetapi menjadi pencipta kerja.

\section{Saran}

Apa yang dicapai responden dalam kajian ini terkait program mahasiswa wirausaha (PMW) mungkin saja belum cukup mewakili seluruh populasi mahasiswa yang memperoleh bantuan dari adanya kebijakan ini. Namun, mencermati secara rinci pengakuan beberapa mahasiswa PMW tersebut, tampaknya perlu dipertimbangkan untuk melanjutkan kebijakan ini sekaligus sebagai salah satu prioritas dari program-program Pemerintah di sektor pendidikan khususnya untuk pendidikan tinggi.

Evaluasi lebih lanjut perlu dilakukan terkait kelayakan besarnya hibah yang diberikan serta total anggaran yang dialokasikan di masing-masing perguruan tinggi. Pada tahun 2009 ini jumlah alokasi anggaran diberikan dalam jumlah yang sama. Misalnya, untuk setiap politeknik diberi-kan anggaran yang sama besar tanpa memper-timbangkan jumlah total mahasiswa di politeknik tersebut. Hal yang sama juga terjadi di universitas, institut atau perguruan tinggi. Tampaknya masalah keadilan belum dapat dibuktikan apabila pola ini digunakan. Pada tahuntahun berikutnya, seyogianya alokasi anggaran ditentukan oleh beberapa faktor di antaranya (1) persentase jumlah mahasiswa yang berminat untuk mengikuti PMW dibandingkan jumlah total mahasiswa, (2) jumlah total mahasiswa, dan (3) jumlah mahasiswa yang telah berhasil pada program ini pada tahun-tahun sebelumnya.

\section{Pustaka Acuan}

BPS/Sakernas Februari 2008. Penduduk Usia Kerja di Indonesia menurut Pendidikan Daerah 2008. Diunduh 25 April 2009 dari: http://www.nakertrans.go.id/pusdatin.html,3,291,pnaker.

Boulton, C dan Turner, F. 2005. Mastering Business in Asia: Entrepeneurship. Wiley MBA Publications.

Direktorat Jenderal Pendidikan Tinggi. 2009a. Naskah Akademik: Upaya Mengurangi Kesenjangan antara Pendidikan Tinggi dan Dunia Bisnis melalui Kompetensi Analitik. Jakarta: Direktorat Jenderal Pendidikan Tinggi.

Direktorat Jenderal Pendidikan Tinggi. 2009b. Pedoman Program Mahasiswa Wirausaha (PMW) Dikti. Jakarta: Direktorat Kelembagaan.

Direktorat Jenderal Pendidikan Tinggi. 2009c. Laporan PMW di Perguruan Tinggi (tidak dipublikasikan). Jakarta: Direktorat Kelembagaan.

Panji Anoraga dan Djoko Sudantoko. 2002. Koperasi, Kewirausahaan dan Usaha Kecil. Jakarta: Rineka Cipta.

Salim Siagian, dan Asfahani. 1997. Kewirausahaan Indonesia dengan Semangat 17-8-1945. Jakarta: PT Kloang Klede Jaya dan Departemen Koperasi dan Pembinaan Pengusaha Kecil.

Suharyadi, Arissetyanto Nugroho, Puwanto, S.K, dan Maman Faturohman. 2007. Kewirausahaan: Membangun Usaha Sukses Sejak Usia Muda. Jakarta: Penerbit Salemba Empat.

Sukidjo. 2011. "Membudayakan Kewirausahaan". WUNY Majalah Ilmiah Populer Tahun XII, Nomor 1, Januari 2011. Yogyakarta: Universitas Negeri Yogyakarta.

Suryana. 2006. KEWIRAUSAHAAN Pedoman Praktis: Kiat dan Proses Menuju Sukses. (edisi 3). Jakarta: Salemba Empat. 